\title{
Buried Treasure or Buried Hope? The Status of Mexico-U.S. Transboundary Aquifers under International Law
}

Gabriel E. Eckstein

Texas A\&M University School of Law, gabrieleckstein@law.tamu.edu

Follow this and additional works at: https://scholarship.law.tamu.edu/facscholar

Part of the Comparative and Foreign Law Commons, Natural Resources Law Commons, and the Water Law Commons

\section{Recommended Citation}

Gabriel E. Eckstein, Buried Treasure or Buried Hope? The Status of Mexico-U.S. Transboundary Aquifers under International Law, 13 Int'I Community L. Rev. 273 (2011).

Available at: https://scholarship.law.tamu.edu/facscholar/129

This Article is brought to you for free and open access by Texas A\&M Law Scholarship. It has been accepted for inclusion in Faculty Scholarship by an authorized administrator of Texas A\&M Law Scholarship. For more information, please contact aretteen@law.tamu.edu. 


\title{
Buried Treasure or Buried Hope? The Status of Mexico-U.S. Transboundary Aquifers under International Law
}

\author{
Gabriel E. Eckstein* \\ Professor of Law, Texas Wesleyan University School of Law, Fort Worth, TX, USA \\ Director, International Water Law Project
}

\begin{abstract}
Transboundary aquifers found along the 2,000 mile-long border between Mexico and the United States are not governed by any treaty. Yet, these aquifers are the primary source of water for many of the twelve million people who live in this parched region. The region's groundwater, however, is being overexploited and contaminated, which is threatening the very life that it currently sustains. As populations continue to expand and current rates of haphazard development persist, the absence of an agreement for the management and allocation of this critical resource could lead to bi-national economic, social and environmental tragedies. This study reviews groundwater resources along the Mexico-United States border and considers the obstacles to the development of an international agreement. It also looks at existing sources of law at the local, regional, national, and international levels of governance. The article offers recommendations that may lead to an amicable arrangement between the two nations.
\end{abstract}

Keywords

groundwater; aquifer; Mexico; United States; transboundary aquifer; international water law; water dispute

\section{Introduction}

The nearly 2000 mile-long border between Mexico and the United States is hot and dry. Few rivers cross this arid expanse. Despite the lack of visible water, though, the region is growing - the combined border population, currently at twelve million, is expected to increase to twenty or more million by $2020 .^{1}$ The reason is ground water; more specifically, transboundary aquifers.

As many as twenty aquifers straddle the Mexico/United States border, many of which serve as the primary source of fresh water for overlying populations. The

\footnotetext{
*) www.InternationalwaterLaw.org, e-mail: geckstein@law.txwes.edu.

1) Good Neighbor Environmental Board, A Blueprint for Action on the U.S.-Mexico Border: Thirteenth Report of the Good Neighbor Environmental Board to the President and the Congress of the United States (2010) p. 3 [hereinafter GNEB 13], available at: http:/www.epa.gov/ocem/gneb/gneb13threport/EnglishGNEB-13th-Report.pdf.
} 
Hueco Bolson Aquifer, for example, provides Ciudad Juárez's 1.5 million residents with all of its water, and two-fifths of that used by El Paso's 730,000 residents. ${ }^{2}$ For other border communities, these aquifers are the only source of fresh water for hundreds of miles, including for the sister cities of Puerto Palomas (Chihuahua) and Columbus (New Mexico), Naco (Sonora) and Bisbee (Arizona), Nogales (Sonora) and Nogales (Arizona), Sonoyta (Sonora) and Lukeville (Arizona), and Tecate (Baja California) and Tecate (California). ${ }^{3}$

Surprisingly, Mexico and the United States have never penned an agreement addressing the allocation and management of these transboundary aquifers. Although a number of pronouncements can be found in a few local arrangements and the Minutes of the International Boundary and Water Commission (IBWC), none offer any substantive guidance as to how the two countries should manage these critical fresh water resources.

As a result, the region's ground water resources, communities, and natural environment are succumbing to depletion and deterioration, thereby threatening the viability of the entire region. Overexploitation on both sides of the border is especially problematic as populations and industries pump with little regard for transboundary impacts or sustainability. Moreover, these finite subsurface reservoirs are being fouled by untreated wastes, agricultural and industrial byproducts, and other sources of pollution.

This article reviews the use of ground water resources along the Mexico-United States border and how growth in populations and economic development has impacted these resources. It also looks at legal sources - from the international to the local level - that may be applicable to this unique border region. Finally, the article identifies the shortcomings of the present situation and offers recommendations for achieving a viable and amicable arrangement between the two nations.

\footnotetext{
2) Z. Sheng \& J. Devere, "Understanding and managing the stressed Mexico-USA transboundary Hueco bolson aquifer in the El Paso del Norte region as a complex system", 13 Hydrogeology J. (2005) p. 813, 814; US Army Corps of Engineers, Army Installations Water Sustainability Assessment: An Evaluation to Vulnerability of Water Supply" ERDC/CERL TR-09-38 (Sept. 2009) p. 103, available at: http://www. dtic.mil/cgi-bin/GetTRDoc?AD=ADA525795\&Location=U2\&doc=GetTRDoc.pdf.

3) Groundwater in the West Conference Reports, 8 University of Denver Water Law Review (2004) p. 328, 335; Terry W. Sprouse, Water Issues on the Arizona-Mexico Border: The Santa Cruz, San Pedro and Colorado Rivers (2005) p. 4, available at: http://www.ag.arizona.edu/azwater/files/terrypaper1.pdf; E.M. Hebard, "Toward jointly managing a transboundary aquifer: Creating a binational dialogue through community participation and education", 44 Arid Lands Newsletter (Fall/Winter 1998), available at: http://ag.arizona. edu/oals/ALN/aln44/hebardfinal.html; U.S. Environmental Protection Agency, Water Supply, Wastewater Collection and Treatment Project for the City of Naco, Sonora, Mexico (1997), available at: http://www.epa .gov/Border2012/infrastructurelbecc/nacofea.pdf.
} 


\section{The Mexico-U.S. Border Region}

The boundary between the Mexico and the United States stretches 1954 miles from the Pacific Ocean to the Gulf of Mexico. ${ }^{4}$ For the most part, it is a dry and arid environment ranging from dry desert in the western portion of the border to semi arid steppe along the Rio Grande in the eastern section. ${ }^{5}$ In the wettest region of the border, the Lower Rio Grande Valley, precipitation averages 500$750 \mathrm{~mm}$ per year; in the driest area along the Sonora/Arizona boundary, it averages $50-100 \mathrm{~mm} .{ }^{6}$ Of particular concern, various climate models suggest that over the next century, the region will become considerably dryer resulting in a reduction in surface runoff of $25 \%$ or more. ${ }^{7}$ See Fig. 1.

Transboundary aquifers, however, underlay large segments of the border region. Numerous wells dot the landscape and peoples on both side of the border rely heavily on the region's ground water resources. Knowledge about the geographic range, volume, flow direction, quality, and renewability of these underground treasurers, though, is limited at best. In fact, the actual number and location of all of the aquifers traversing the border has yet to be formally determined. For example, although the Good Neighbor Environmental Board, an independent U.S. Presidential advisory committee, suggested in its 2005 report that eighteen to twenty aquifers may underlie the border, ${ }^{8}$ in its 2010 report, the GNEB asserted that the number of transboundary aquifers is difficult to estimate because of a lack of accurate data. ${ }^{9}$ Other studies suggest that there are as few as eight ${ }^{10}$ and as many as eighteen. ${ }^{11}$

Despite the lack of information on water availability, growth along the border is booming. Between 2000 and 2010, the region's population grew by $16 \%$ to

\footnotetext{
4) Boundary Map, International Boundary \& Water Commission, available at: http://www.ibwc.gov/ Files/US-Mx_Boundary_Map.pdf.

5) Transboundary Freshwater Dispute Database, available at: http://ocid.nacse.org/tfdd/index.php.

9) National Water Commission of Mexico, "Statistics on Water in Mexico" (2010) p. 27, available at: http://www.conagua.gob.mx/CONAGUA07/Publicaciones/Publicaciones/SGP-6-10-EAM2010Ingles. pdf.

7) Id. at 177; GNEB 13, supra note 1, at 10.

8) Good Neighbor Environmental Board, Water Resources Management on the U.S.-Mexico Border Eighth Report to the President and Congress of the United States (2005) p. 24, available at: http://www.epa.gov/ ocem/gneb/gneb8threport/gneb8threport.pdf.

9) GNEB 13, supra note 1 , at 31 .

10) UNESCO 2005 Final Report: 2nd Coordination Workshop. UNESCO/OAS ISARM Americas Programme - Transboundary Aquifers of the Americas, El Paso, TX, 10-12 November 2004, available at: http://www.oas.org/dsd/isarm/Documents/English/ISARM\%20Americas\%202004-\%20El\%20 Paso\%20Workshop\%20Report.pdf.

11) S. Mumme, "Minute 242 and beyond: challenges and opportunities for managing transboundary groundwater on the Mexico-US border", 40 Natural Resources Journal (2000) p. 341 (referencing 18 transboundary aquifers). The most recent assessment of transboundary aquifers globally, prepared by the International Hydrological Programme of the U.N. Educational, Scientific and Cultural Organization, reports 10 transboundary aquifers on the Mexico-U.S. border. Atlas of Transboundary Aquifers (2009) p. 94, available at: http://www.isarm.net/publications/322.
} 


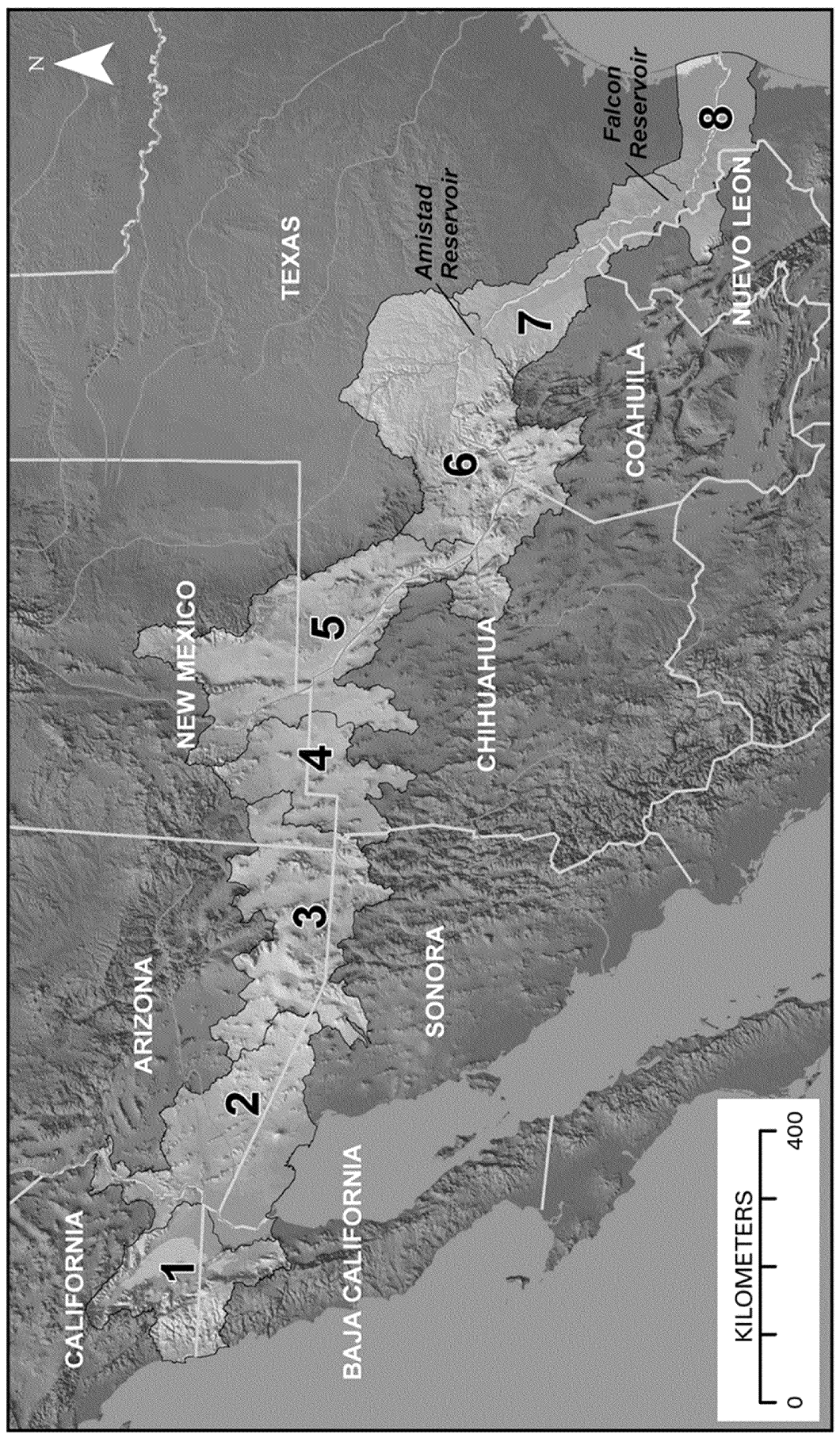

$\stackrel{\square}{2}$

ت्ञ

氖

离

3

ㅁ

ప

5

音

Е

$\frac{n}{\tilde{u}}$

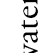

y

$\stackrel{\breve{g}}{\exists}$

寻

‡.

च्

(1)

를

50

ํㅡㄹ

$\frac{7}{60}$

晌

¿

สิ

त च

홓

:

बे

尝

क ज

?

0.8

ஸे

它 
14.4 million. ${ }^{12}$ Much of this growth has taken place in the fourteen "sister cities" that share the border. ${ }^{13}$ With a population growth rate exceeding average rates in Mexico and the United States by 2 to 3.5 percent, the border region is expected to reach 20 million people by $2020 .{ }^{14}$ As a result, reliance on the region's transboundary aquifers is also growing. In Arizona and Sonora, for example, municipal demand for water is expected to double over the next 10-20 years. ${ }^{15}$

Over the many years of unrestricted exploitation, though, the region's aquifers have been slowly depleted. For example, between 1952 and 2007, the water table of the Hueco Bolson aquifer, which underlies both Ciudad Juárez and El Paso, fell by approximately 76 feet. ${ }^{16}$ In 2001, total withdrawals from that aquifer equalled 312 million cubic meters (MCM) - $155 \mathrm{MCM}$ on the Mexican side and 62.2 MCM on the U.S. side - while natural and artificial recharge totalled a mere 9.6 MCM. $^{17}$

Similarly, the lack of regulation has allowed the degradation and contamination of these critical resources. In the US State of New Mexico alone, between 1927 and 2000, the New Mexico Environment Department identified more than 1,400 cases of groundwater contamination originating from a variety of point and non-point sources, including domestic septic tanks and cesspools discharging around 94 million gallons of wastewater per day into the subsurface. ${ }^{18}$

\section{Constraints to Cooperation: Ground Water Law on the Border}

Presently, there exists no comprehensive agreement between Mexico and the United States on the regulation, management, allocation, or protection of the numerous aquifers straddling the border-region. This absence, however, does not mean that there is no law on the border pertaining to ground water resources. In fact, there are numerous sources of law that, to varying degrees, are relevant to these border resources. This multiplicity of legal regimes and jurisdictions, however, is one of the most vexing challenges to the development of robust bi-national cooperation.

\footnotetext{
12) GNEB 13, supra note 1, at 3.

13) $I d$.

14) $I d$.

15) Id. at 610.

16) US Army Corps of Engineers, supra note 2, at 106.

17) Sheng \& Devere, supra note 2, at 817; US Army Corps of Engineers, supra note 2, at 106.

18) New Mexico Environment Department, The State of the Environment: 2001 Report (2001) p. 26; D. McQuillan, et al., Ground Water: New Mexico's Buried Treasure, New Mexico Environment Department (2000, revised May 2006) p. 3.
} 


\subsection{Treaty Law}

\subsubsection{Minutes of the International Boundary and Water Commission}

The International Boundary and Water Commission (IBWC) is a bi-national commission, composed of a Mexican and a United States section, responsible for enforcing water treaties and settling border disputes. ${ }^{19}$ It carries out its mandate and commitments by formulating Minutes - decisions or recommendations, which, once approved by both governments, become binding on the countries. ${ }^{20}$ Of the more than 300 Minutes, only two specifically refer to transboundary ground water resources in the border region. Although crafted to focus on salinity levels in the Colorado River, Minute 242 of 1973 also limits ground water withdrawals on both sides of the Sonora-Arizona border near San Luis to specifically enumerated withdrawal targets. ${ }^{21}$ This limitation was intended to be temporary pending the development of a "comprehensive" ground water agreement for the border region, which has yet to occur. ${ }^{22}$ In addition, the Minute requires both countries to consult each other prior to pursuing new development of surface or ground water resources, or any other action, that could adversely impact the other country. ${ }^{23}$ Minute 289 of 1992 addresses water quality along the Mexico-U.S. border. ${ }^{24}$ Although it primarily focuses on the Rio Grande and Colorado rivers, Paragraph 4 references the 1992 Integrated Border Environmental Plan that calls for creating a water-monitoring program and database to observe surface and ground water quality along the Mexico-U.S. border. ${ }^{25}$

\subsubsection{Law Paz Agreement}

The Mexico-U.S. Agreement on Cooperation for the Protection and Improvement of the Environment in the Border Area (La Paz Agreement) does not reference or focus on ground water resource. ${ }^{26}$ Rather, it obligates the parties to:

\footnotetext{
19) S. Mumme, "Innovation and Reform in Transboundary Resource Management: A Critical Look at the International Boundary and Water Commission, United States and Mexico", 33 Natural Resources Journal (1993) pp. 93, 94-95. The Commission's current structure and water mandate originates with the 1944 Treaty between the United States of America and Mexico relating to the utilization of the Waters of the Colorado and Tijuana Rivers and of the Rio Grande, 59 Stat. 1219 (Nov. 14, 1944), available at: http:// www.ibwc.gov/Files/1944Treaty.pdf.

20) A. Szekely, How to Accommodate an Uncertain Future into Institutional Responsiveness and Planning: The Case of Mexico and the United States, 33 Natural Resources Journal (1993) pp. 397, 398.

21) Minute 242: Permanent and Definite Solution to the International Problem of the Salinity of the Colorado River. International Boundary and Water Commission (August 30, 1974), at Parag. 5, available at: http://www.ibwc.gov/Files/Minutes/Min242.pdf.

22) Id.

23) Id. at para. 6.

24) Minute 289: Observation of the Quality of the Waters Along the United States and Mexico Border. International Boundary and Water Commission (December 11, 1992), available at: http://www.ibwc.gov/ Files/Minutes/Min289.pdf.

25) Id.

26) United States of America and the United Mexican States Agreement on Cooperation for the Protec-
} 
prevent, reduce, and eliminate sources of pollution in their respective territory where such pollution affects the others' border region; cooperate in addressing environmental problems of mutual interest; and coordinate practical, legal, institutional and technical measures designed to protect environmental quality in the border area, including coordinating national programs, scientific and educational exchanges, environmental monitoring, environmental impact assessment, and regular exchanges of data and information on transboundary pollution originating each country's territory. ${ }^{27}$ Presumably, though, these obligations encompass the region's transboundary aquifers.

\subsection{Customary International Law}

Today, there is a clear consensus to the existence of customary international law (CIL) for transboundary lakes and river. ${ }^{28}$ In contrast, the existence of CIL for transboundary ground water resources is less clear and a review of existing state practice indicates that it is still in a nascent state. ${ }^{29}$

Possibly, the best evidence supporting the existence of CIL for transboundary aquifers is found in the UN General Assembly (UNGA) Resolution on the Law of Transboundary Aquifers (Resolution). ${ }^{30}$ The nineteen draft articles contained in the Resolution were formulated by the UN International Law Commission as part of its continuing mandate to codify and progressively develop international water law. ${ }^{31}$

The chief substantive state obligations identified in the draft articles include the well-known international water law rules of equitable and reasonable utilization and no significant harm. The first provides that all aquifer states must ensure that their utilization of a transboundary aquifer is both equitable, in terms of the benefits derived from the use of the aquifer, and reasonable overall. Equity and reasonableness are assessed by evaluating a variety of factors, among them: the population dependent on the aquifer: social, economic and other needs of the aquifer states concerned; and actual and potential effects of the aquifer's use on

\footnotetext{
tion and Improvement of the Environment in the Border Area (14 August 1983), available at: http:// www.usembassy-mexico.gov/eng/lapaz.html.

27) Id. at Arts. $2 \& 6$.

28) See generally S. McCaffrey, The Law of International Watercourses 2nd (2007).

29) G. Eckstein, "Managing Hidden Treasures across Frontiers: The International law of Transboundary Aquifers", in UNESCO, Pre-Proceedings of the UN Educational, Scientific and Cultural Organization Conference: Transboundary Aquifers - Challenges and New Directions, 6-8 December 2010, Paris, France [hereinafter Eckstein Hidden Treasures].

30) United Nations, Resolution adopted by the General Assembly, The Law of Transboundary Aquifers, A/RES/63/124 (2008) [hereinafter UN Resolution], available at: http://www.internationalwaterlaw.org/ documents/intldocs/UNGA_Resolution_on_Law_of_Transboundary_Aquifers.pdf.

31) Gabriel Eckstein, "Commentary on the U.N. International Law Commission's Draft Articles on the Law of Transboundary Aquifers”, 18 Colorado Journal of International Environmental Law \& Policy (2007) pp. 537, 541-42 [hereinafter Eckstein Commentary].
} 
other aquifer states. ${ }^{32}$ The latter obligation binds aquifer states to ensure that activities related to a shared aquifer do not result in significant harm to other aquifer states. ${ }^{33}$ The threshold of "significant" is regarded as a "flexible and relative concept" that is to be judged in relation to the totality of the circumstances..$^{34}$

The no significant harm rule also obligates aquifer States not to cause significant harm through "activities other than utilization of a transboundary aquifer... that have, or are likely to have, an impact upon that transboundary aquifer." ${ }^{35}$ This latter modification specifically relates to the distinct likelihood that nonaquifer utilization activities undertaken above or around aquifers could detrimentally affect those aquifers, such as industrial and agricultural operations in the recharge zone, mining activities in the aquifer matrix, and construction, forestry, and other activities that might affect the normal recharge process. ${ }^{36}$ Other noteworthy principles found in the Resolution include obligations to regularly exchange data and information, protect ecosystems, protect recharge and discharge zones, prevent pollution, monitor the aquifer, and prior notification of planned activities. ${ }^{37}$

\subsection{Domestic Laws}

Although there are only two nations involved, both Mexico and the United States operate as federations whereby their respective member states enjoy partial selfgoverning status. While the domestic laws of nations do not control transboundary interactions, they nevertheless can have considerable implications for the development of these relations. To varying extents, the laws of sub-national jurisdictions can constrain the ability of the national government to enter into arrangements with or make commitments to other nations. This has been especially complicated on the U.S. side where the four border-states retain considerable sovereignty over their ground water resources. As noted by the GNEB, "Coordination on shared aquifers is difficult because groundwater is controlled by state governments in the United States and the federal government in Mexico."38

\footnotetext{
32) UN Resolution, supra note 36, at Arts. 4-5.

33) Id. at Art. 6

34) C. Yamada, Second Report on Shared Natural Resources: Transboundary Groundwaters, U.N. Doc. A/CN.4/539 (2004), I25; General Assembly Official Records, Report of the International Law Commission on the Work of its Fifty-Eighth Session, Shared Natural Resources, 61st Session, Supplement No. 10 (A/61/10) (2006), $\mathbb{2}$, at 193.

35) Id. at Art. 6.

36) Eckstein Commentary, supra note 37, at 545.

37) UN Resolution, supra note 36, at Arts. 8, 10, 11, 12, 13, and 15.

38) GNEB 13, supra note 1, at 31.
} 


\subsubsection{Mexico}

The Mexican national constitution explicitly reserves to the federal government the authority to regulate all aspects of surface and ground water resources. ${ }^{39}$ This authority is implemented through the Comisión Nacional del Agua (CONAGUA), which subjects all water users to a regulated permitting process. This standardized approach creates considerable uniformity throughout Mexico and allows the federal government leeway in negotiating with its neighbours over transboundary waters. The same cannot be said for water law in the United States.

\subsubsection{United States}

Under the U.S. federal structure, the allocation and management of fresh water resources is largely devolved to the states. Although water quality issues have been subsumed within a series of federal laws relating to the environment and human health, under the federal government's constitutional authority to regulate commerce and protect the public welfare, such as the Clean Water Act ${ }^{40}$ and Safe Drinking Water Act, ${ }^{41}$ the allocation and management of fresh water resources are within the purview of each individual state. This includes the determination and distribution of water rights. ${ }^{42}$

This bifurcated system of management is largely the result of the politics surrounding fresh water in the United States and the long-held understanding that because water rights (including usufructuary rights) are considered property rights, they should be subject to state rather than federal law. As a result, the interests and priorities of the various states have evolved separately and allowed for the implementation of dissimilar set of laws in each jurisdiction for ground water management. These interests, priorities, and laws often conflict with those of neighbouring states, and constrain the ability of the United States to present a unified national position on transboundary ground water management. While the federal U.S. government could find constitutional grounds to assume regulatory authority over waters traversing international boundaries, given the politics surrounding fresh water in the United States (especially in the American West), it would do so at its electoral peril. The result is a highly decentralized system that imposes multiple layers of complication for any effort seeking cooperation over transboundary ground water resources along the Mexico-U.S. border.

\footnotetext{
39) Art. 27, Political Constitution of the United Mexican States of 1917 (as amended): "The property of all land and water within national territory is originally owned by the Nation, who has the right to transfer this ownership to particulars."

40) 33 U.S.C. $\$ 1251-1387$ (2006).

41) 42 U.S.C. $\$ 300 f-j$ (2006).

42) R.H. Abrams, Water Law; Trends, Policy and Practice (1995), p. 330.
} 


\subsubsection{Texas Ground Water Law}

Following the so-called "Rule of Capture," landowners in Texas are entitled to withdraw ground water from beneath their land regardless of the impact their pumping may have on neighbouring landowners or other hydraulically related waters. ${ }^{43}$ This is because ground water in Texas is not owned by the state, but rather is considered a property right that is attached to the ownership of overlying land. Liability may only lie where extraction: 1) is pursued for the purpose of harming a neighbouring landowner, 2) results in the waste of water, or 3) negligently causes subsidence of neighbouring properties. ${ }^{44}$ Texas courts, however, have interpreted the Rule of Capture rather liberally and have rarely found a violation of the Rule.

The Rule of Capture, however, has been tempered in those areas of Texas that have created ground water conservation districts. These local governmental units have regulatory authority to impose well-spacing controls, withdrawal limitations, and other restrictions on ground water use. The authority granted, however, has come with few guidelines from the state, thereby resulting in little standardization among the rules of the various districts. ${ }^{45}$ Of the 96 confirmed districts in the state, 5 share a border with Mexico. ${ }^{46}$

\subsubsection{New Mexico Ground Water Law}

In contrast to Texas, ground water in New Mexico is owned by the state on behalf of the citizens and is allocated according to the prior appropriation doctrine. ${ }^{47}$ Under this system, ground water use is regarded as a privilege rather than an absolute property right. Water use is allocated through permits issued by the state engineer that are enforced in accordance with the principle of "first in time, first in right" - in times of drought or other water scarce conditions, users with more senior (older) permits have a right to their full allocation before those with junior (younger) permits can enjoy their allotment. ${ }^{48}$ Although under prior appropriation, ground water use is restricted for beneficial purposes, the state's courts have broadly interpreted what uses may be considered beneficial.

43) Sipriano v. Great Spring Waters of America, Inc., 1 S.W.3d 75, 76 (Tex. 1999).

44) Id. at 77-78.

45) Tex. Water Code $\$$ 36.101(a). See also Texas Commission on Environmental Quality, Summary Description of GCDs (July 2010), available at: http://www.tceq.state.tx.us/assets/public/permitting/water supply/groundwater/maps/gcd_text.pdf.

46) The boundaries of all five districts comport with the boundaries of their namesake counties: Brewster, Jeff Davis Kinney, Presidio, and Starr counties. See Map: Ground water Conservation Districts, Texas Water Development Board (September 2010), available at: http://www.twdb.state.tx.us/mapping/maps/ pdf/gcd_only_8x11.pdf.

47) Art. XVI, $\$ 2$, New Mexico Constitution.

48) N.M. Stat. Ann. $\$ 72-12-1.1$ (LexisNexis 2003); Bureau of Land Management, "New Mexico Water Rights Fact Sheet” 1 (2001), available at: http://www.blm.gov/nstc/WaterLaws/pdf/NewMexico.pdf. 


\subsubsection{Arizona Ground Water Law}

Arizona applies the doctrine of reasonable use to ground water management and allocation. Under this regulatory scheme, landowners may pump underlying ground water for reasonable uses on overlying land. The reasonableness of a particular use is assessed based on a totality of circumstances and considers such factors as well location, the amount of water used, the purpose of the use, the placement of the water, and the extent to which the use may be wasteful. ${ }^{49}$ Where there is inadequate water for two reasonable uses, the courts have tended to reduce the allocations of the users on a pro rata basis. The use of ground water on nonoverlying land, however, is permitted only where it does not damage or impair the water supply of another landowner who is making reasonable use on land overlying the same ground water basin. ${ }^{50}$ Ground water withdrawal is also constrained where it tends to diminish the flow of a surface stream appreciably and directly. ${ }^{51}$ In addition, Arizona has created Groundwater Management Areas in which a variety of additional local ground water use restrictions are implemented in relation to both water needs and availability. ${ }^{52}$

\subsubsection{California Ground Water Law}

Of the four US states, California may have the most confounding series of rules for ground water resources in that California employs both prior appropriation and correlative rights schemes to their ground water resources. Under correlative rights, landowners overlying an aquifer have an equal right to a "fair and just proportion" of the underlying water for reasonable beneficial uses on their overlying land. The notions of fairness, reasonableness, and beneficial use have been liberally interpreted by the California courts. In times of shortage, each correlative overlying user may use only a reasonable amount. In contrast, groundwater users who use the water on non-overlying land are considered appropriators much like prior appropriators in New Mexico. As between two appropriators, the rule of "first in time, first in right" applies. Where an appropriator's use conflicts with that of an overlying user applying the water on overlying land, the latter's rights are absolutely superior to those of the former. ${ }^{53}$

\footnotetext{
49) Bristor v. Cheatham, 75 Ariz. 227, 236-38 (1953).

50) Neal v. Hunt, 541 P.2d 559, 565-66 (Ariz. 1975).

51) In re the General Adjudication of All Rights to Use Water in the Gila River System and Source, 195 Ariz. 411, I8 (1999).

52) K.L. Patrick \& K.E. Archer, "A Comparison of State Groundwater Laws", 30 Tulsa Law Journal (1994) pp. 123, 133-35.

53) J.M. Miller, "When Equity is Unfair - Upholding Long-Standing Principles of California Water Law in City of Barstow v. Mojave Water Agency", 32 McGeorge Law Review (2001) pp. 991, 994-95; G. Bryner and E. Purcell, Groundwater Law Sourcebook of the Western United States, Natural Resources Law Center, University of Colorado at Boulder (2003).
} 


\subsection{Subnational Transboundary Arrangements}

Like the domestic laws of states, subnational transboundary arrangements cannot create binding obligations on a nation. In practical terms, though, these unofficial pacts can have profound implications for the development of international law, at the very least, as between the nations whose subnational entities entered into an arrangement. $^{54}$

An example of a subnational arrangement along the Mexico-U.S. border is that of the 1999 Memorandum of Understanding between City of Juárez, Mexico Utilities and the El Paso Water Utilities Public Services Board of the City of El Paso, Texas (MoU). ${ }^{55}$ Although legally unenforceable, this $\mathrm{MoU}$ was entered into by the two utilities to "identify the mechanisms between the parties to increase communications, cooperation, and implementation of transboundary projects of common interest." Moreover, the arrangement alludes to data and information sharing related to transboundary natural resources, and cooperation in the management, use and protection of natural resources that traverse the international boundary. ${ }^{56}$

\section{Transboundary Ground Water Cooperation: The Way Forward}

With some exceptions, Mexico and the United States continue to take a unilateral approach to the management of the transboundary aquifers underlying their shared border. Locals on each side of the border have constructed wells and are withdrawing ground water in response to increasing demands of population growth and economic development, and with little regard for the consequences of their independent or collective actions on the region's transboundary aquifers. In order for the two nations to develop a sustainable management regime that responds to the needs of both nations, Mexico and the United States must adopt a new paradigm for cooperation over their transboundary aquifers. Two meaningful steps that would put the two nations on a path toward such cooperation include: 1) pursuing aquifer-specific arrangements rather than a single borderwide agreement; and 2) emphasizing procedural cooperative mechanisms over a determination of substantive rights and allocations.

\footnotetext{
54) See generally G. Eckstein and A Hardberger, "State Practice in the Management and Allocation of Transboundary Ground Water Resources in North America”, 18 Yearbook of International Environmental Law 2007 (2008) p. 96.

55) Memorandum of Understanding between City of Juárez, Mexico Utilities and the El Paso Water Utilities Public Services Board (PSP) of the City of El Paso, Texas (6 December 1999), available at: http:// internationalwaterlaw.org/documents/regionaldocs/Local-GW-Agreements/El_Paso-Juarez_MoU.pdf. 56) Id.
} 


\subsection{Aquifer-Specific Arrangements Rather than a Comprehensive Agreement}

Rather than pursuing a broad-based transboundary aquifers agreement that applies to all aquifers on the border, Mexico and the United States should pursue aquifer or aquifer system-specific arrangements. While such an approach may be more complex and require considerably more time to accomplish, it is likely to be more successful than would a comprehensive regime at promoting transboundary cooperation and sustainable aquifer management along the border.

The chief rationale for an aquifer-specific approach is that, in many contexts, a comprehensive agreement could be ineffective and even detrimental where it seeks to apply to multiple transboundary water bodies that have disparate characteristics and functions. This is especially true for transboundary aquifers, which can be locally unique and require distinct management, allocation, or protection regimes.

The Mimbres Basin Aquifer, for example, which underlies the border-states of New Mexico in the United States and Chihuahua in Mexico, is part of a closed or terminal drainage basin, ${ }^{57}$ is highly dependent on the Mimbres River for its recharge, and is discharged predominantly by agriculture-related pumping activities. ${ }^{58}$ In contrast, the Rio Grande Aquifer, which follows and underlies much of the upper Rio Grande and traverses the Mexico-U.S. border in the greater El Paso / Ciudad Juárez area, is recharged primarily from the application of surface water to irrigable crops and to a lesser extent by direct seepage from canals and river channels. Additionally, the Rio Grande Aquifer discharges into the adjacent Rio Grande and the Hueco Bolson Aquifer, as well as through irrigation pumping. ${ }^{59}$ While agricultural withdrawals are a significant source of discharge for both aquifers, the differences in additional discharge mechanisms, recharge sources, hydrological and geomorphological framework, and other features necessitate a tailored approach in relation to local conditions. In addition, aquifers often affect communities with distinctive and occasionally singular social, developmental, cultural, or other characteristics that require very specific considerations. ${ }^{60}$ Accordingly, while concerns addressed in disparate regions may appear facially similar, the water challenge in each can be locally unique necessitating locally tailored solutions.

\footnotetext{
57) A "closed basin" is an enclosed topographic basin or depression that has no external drainage. Water within such basins can only exit the basin through evaporation of human use.

58) See J.W. Hawley et al., Transnational Boundary aquifers in Southwestern New Mexico, N.M. Water Resources Research Institute, 30, 36-38 (2000), available at: http://wrri.nmsu.edu/publish/otherrpt/ swnm/DjVu/downl.html.

59) International Boundary \& Water Commission, United States Section, Transboundary Aquifers and Binational Ground Water Database for the City of El Paso / Ciudad Juarez Area, available at: http://www. ibwc.gov/Water_Data/binational_waters.htm.

60) See e.g., Hector M. Arias, "International Groundwaters: The Upper San Pedro River Basin Case", 40 Natural Resources Journal (2000), p. 199.
} 
Priorities on the border are often not those found within the national legislatures and executive offices; the degree of interest that a national government has in local issues is often in direct proportion to the distance the issue lies physically from the capital. Hence, efforts to achieve a thoughtful, environmentally sound, and internationally equitable management and allocation regime for a transboundary aquifer is more likely to succeed if it involves and is driven by local participation and decision-making on both sides of the border. This local approach, is based on the fact that local decision-making will tend to be better informed, is more likely to reflect the values and preferences of those most affected, is more flexible and adaptable to changing conditions and new information, and is more likely to result in sustainable solutions. ${ }^{61}$

\subsection{Procedural Mechanisms over Substantive Rules}

One of the complexities of achieving transboundary water cooperation is the determination of states' substantive water rights. Under international water law, states are entitled to the equitable and reasonable utilization of transboundary waters - both surface and ground waters - as well as the right not to suffer significant harm from the use of those waters by other riparian and aquifer states. ${ }^{62}$ Yet, the determination of what these substantive rights entail, especially in terms of actual water allocations, is fraught with difficulties and can become an obstacle to cooperation and the formulation of a transboundary water accord. ${ }^{63}$ This is the result of sovereignty, which infuses nations with a sense of entitlement as well as a legal basis supporting their claims. Any interference with a state's rights over its natural resources is an infringement of its sovereignty.

In sharp contrast, cooperation over procedural conditions related to transboundary waters is considered, by most nations, as a lesser menace, or even a non-threat, to sovereignty. This is because procedural cooperation tends only to impose obligations related to information about shared waters rather than about ownership in and rights to those waters. As a result, states with little information about their transboundary aquifers and those with a history of animosity or con-

61) J.L. Huffman, "Making Environmental Regulations More Adaptive Through Decentralization: The Case for Subsidiarity", 52 University of Kansas Law Review (2004) pp. 1377, 1378, 1381-1382. In the European context, the emphasis on local decision-making is known as subsidiarity, a legal norm that allows for decision-making at the lowest level of competent authority. See R.K. Vischer, "Subsidiarity as a Principle of Governance: Beyond Devolution", 35 Indiana Law Review (2001) pp. 103, 142; Paolo G. Carozza, "Subsidiarity as a Structural Principle of International Human Rights Law", 97 American Journal of International Law (2003) pp. 38, 42.

62) Eckstein Hidden Treasures, supra note 35.

63) An example in which negotiations over water rights hindered development of cooperative water arrangements is the Israeli/Palestinian negotiations over the Jordan River and Mountain Aquifer. See I. Fischhendler, A.T. Wolf, and G. Eckstein, "The Role of Creative Language in Addressing Political Realities: Middle-Eastern Water Agreements", in Aridity, Scarcity and Shared Water Resources: Arizona, Israeli and Palestinian Perspectives on Solving Water Management Challenges (forthcoming UNESCO, 2011). 
ditions disfavouring water allocations may be more apt to enter into water-related arrangements that only require procedural obligations than to agree to arrangements that also address substantive water rights. ${ }^{64}$

\subsubsection{Examples of Procedural Mechanisms}

One of the most essential procedural requirements for transboundary waters is the regular exchange of data and information. Absent such an exchange, aquifer states would be unable to fully project and mitigate deleterious natural and human impacts to the aquifer or to protect and sustainably manage the aquifer into the future. Essentially, the obligation requires Mexico and the United States to exchange data and information related to the character, use, and functioning of each transboundary aquifer. ${ }^{65}$ This can include material of a "geological, hydrogeological, hydrological, meteorological and ecological nature and related to the hydrochemistry of the aquifers or aquifer systems, as well as related forecasts." 66

As noted above, four reports offer four different conclusions as to the number and locations of aquifers traversing the Mexico-U.S. border, ranging from as few as eight to as many as twenty. ${ }^{67}$ While a few of the aquifers have been studied and characterized - most famously the Hueco Bolson underlying Ciudad Juárez and El Paso $^{68}$ - the extent of information about the region's remaining aquifers is scant and dispersed. Many of the studies are conducted independently on each side of the border, use disparate scientific standards, collect dissimilar data, and generate maps and conceptual models that "end" at the border. ${ }^{69}$ As described by the GNEB, researchers and water managers "often are faced with the 'blank map' syndrome in which a transboundary aquifer is mapped by an entity in the United States but, because the U.S. researcher lacks access to Mexican data, the portion of the aquifer south of the border shows up completely blank on the map (the same problem occurs north of the border for the Mexican researcher)." 70

A corollary procedural duty to the obligation to exchange data and information is the requirement to generate additional data and information through

\footnotetext{
64) Two aquifer agreements that may have developed along this line of reasoning include: Programme for the Development of a Regional Strategy for the Utilisation of the Nubian Sandstone Aquifer System (NSAS) - Terms of Reference For the Monitoring and Exchange of Groundwater Information of the Nubian Sandstone Aquifer System [Tripoli, 5 October 2000], available at: http://www.fao.org/ docrep/008/y5739e/y5739e05.htm; and Establishment of a Consultation Mechanism for the Northwestern Sahara Aquifer System (SASS) [2002], available at: http://www.fao.org/docrep/008/y5739e/ y5739e05.htm\#bm05.2.1.

65) $I d$.

66) Resolution adopted by the UN General Assembly: The Law of Transboundary Aquifers, A/RES/63/124 (2008).

67) See supra notes 10 to 13 , and accompanying text.

68) International Boundary and Water Commission, Transboundary Aquifers and Binational GroundWater Database: City of El Paso/Ciudad Juarez Area - Final Report (January 1998).

69) Sheng \& Devere, supra note 2 , at 818-819.

70) GNEB 13, supra note 1, at 31.
} 
monitoring and related activities. Indispensible to fulfilling the duty to exchange, this obligation recognizes the need to maintain vigilance in managing transboundary aquifers and to systematically and continuously check on an aquifer's physical characteristics, as well as activities related to the aquifer's utilization and the possible impact they may have on the aquifer.

Also related to the obligation to exchange data and information is the need to harmonize methodologies, techniques, procedures, assumptions, and technologies collectively known as metadata ${ }^{71}$ - used in the generation and processing of data and information. Disparate approaches and instrumentation used to assess aquifer characteristics, such as rate of flow, hydraulic potential, and chemical composition, can produce incongruent results. This is due to the multitude of factors and assumptions that go into the analytical process of aquifer assessment, but may also be caused by differences in researchers' education, training, experience, or preferences. ${ }^{72}$ Hence, to ensure that mismatched data and information do not hinder cross-border cooperation, it is critical that Mexico and the United States cooperate to harmonize the metadata early in any coordination over a transboundary aquifer.

Lastly, to encourage procedural cooperation without significantly infringing on each other's sovereignty, Mexico and the United States should adopt prior notification requirements. Such a system would obligate both states to inform each other of planned activities that may have an adverse impact on a transboundary aquifer or the territory of the other state. It would allow each state to evaluate possible consequences for themselves and to seek an understanding or compromise where an impact may be deemed unacceptable. ${ }^{73}$ While detailed, customarily accepted procedures for advance notification in the context of transboundary aquifers has yet to be articulated, ${ }^{74}$ a general notice requirement for plans to exploit a transboundary natural resource is already part of customary international law. ${ }^{75}$

\footnotetext{
71) According to the U.S. Geological Survey (USGS), metadata consisting "of information that characterizes data. Metadata are used to provide documentation for data products. In essence, metadata answer who, what, when, where, why, and how about every facet of the data that are being documented." USGS Website, http:/geology.usgs.gov/tools/metadata/tools/doc/faq.html\#q1.1 (emphasis in original).

72) Eckstein Commentary, supra note 37, at 581-82.

73) Eckstein Hidden Treasures, supra note 35.

74) See General Assembly Official Records, Report of the International Law Commission on the Work of its Fifty-Eighth Session, Shared Natural Resources, 61st Session, Supplement No. 10 (A/61/10) (2006), I1, at 230 (Commentary on Draft Art. 14), available at http://untreaty.un.org/ilc/reports/2006/2006report. htm.

75) See Owen McIntyre, "The Role of Customary Rules and Principles of International Environmental Law in the Protection of Shared International Freshwater Resources", 46 Natural Resources Journal (2006) pp. 157, 180-86; see generally Daniel G. Partan, “The 'Duty to Inform' in International Environmental Law”, 6 Boston University International Law Journal (1988), p. 43.
} 


\subsubsection{Procedural Mechanisms on the Mexico-U.S. Border}

In the Mexico-U.S. context over transboundary ground water resources, there is evidence that a procedures-focused approach is currently being pursued. In addition to the MoU entered into by the water utilities of Juárez and El Paso, the IBWC has a long-established relationship of cooperation between its Mexican and United States sections that has occasionally pertained to transboundary aquifers. As noted above, Minute 289 calls for the creation of a water quality monitoring program and database along the Mexico-U.S. border. ${ }^{76}$ Moreover, Minute 242 implements a consultation requirement prior to undertaking all freshwater resource-related development projects in the border region that could adversely impact the other country. ${ }^{77}$

In addition, on August 19, 2009, the Mexican and American sections of the IBWC adopted a joint cooperative process (JCP) to implement a transboundary aquifers assessment program for the shared aquifers traversing the common border. Intended "to improve the knowledge base" of transboundary aquifers in the border region, the JCP outlines procedures for identifying and studying specific transboundary aquifers as well as for coordinating study activities on both sides of the border. Significantly, the JCP explicitly excludes issues related to sovereignty and water rights by noting that nothing in the agreement "will limit what either country can do independently in its own territory," and that data resulting from the JCP "is solely for the purpose of expanding knowledge of the aquifers and should not be used by one country to require that the other country modify its water management and use." 78

All of these efforts are great examples of procedural mechanisms achieving productive results along the Mexico-U.S. border. While they may not achieve equitable allocation or sustainable management of the region's transboundary aquifers, they provide the two countries with opportunities to generate muchneeded information and strengthen transboundary water relations that may yet lead to the determination of substantive rights. Accordingly, more of these mechanisms should be implemented for each transboundary aquifer traversing the border.

\section{Conclusion}

Transboundary aquifers undeniably are the most critical natural resource on the Mexico-U.S. border. Unfortunately, those underground treasures have been

\footnotetext{
76) Minute 289, supra note 27.

77) Minute 242, supra note 23.

78) International Boundary and Water Commission, Joint Report of the Principle Engineers Regarding the Joint Cooperative Process, United States-Mexico for the Transboundary Aquifer Assessment Program (19 August 2009), available at: http://www.ibwc.gov/Files/Minutes/Joint_Report_TAAP_081909.pdf.
} 
depleted, polluted, and disregarded for too many years. Although there now is a growing interest in ensuring the sustainability of these resources into the future, whether that objective can be achieved will greatly depend on the ability of the two neighbours to cooperate and coordinate activities related to the exploitation and protection of the ground water resources traversing this arid expanse. While a comprehensive allocation and management regime may be an ambitious goal, pursuing procedural cooperative mechanisms could lay the ground work for such aspirations and provide the tools for their realization. At the very least, such procedures would implement the principles of good neighbourliness and cooperation, notions that already bind the two states under general international law. 